Mr. N. M. Knipowitsch has compiled a volume of more than 1500 pages, embodying the results of much research, under the title of "Bases of the Hydrology of the European Ice-ocean" (i.e. Barents and the White Seas). The author proposes to give a full and exact picture of the physical geography of the ice-ocean, so far as that is possible at the present time, to record some deductions with regard to biology and geology, and to construct a firm groundwork for future investigations. $\mathrm{He}$ modestly leaves his conclusions open for future proof, but none the less must be congratulated on the accomplishment of this work, which will unquestionably be of great value to students of marine conditions. Accordingly, Mr. Knipowitsch reviews previous literature, gives lists of temperature at many points, tables indicating degrees of saltness, differences of temperature according to depths, analyses of sea-water, its clearness and colour, with chapters on hydrology, biology, and geology, a series of about sixty practical deductions, and appendices. A short abstract in German appears at the end. The author refers to other works of his own, to Scandinavian authorities, e.g. Nansen and Pettersson, and to men of a former generation, as Scoresby, and the Siberian explorer Middendorf.

Vol. xxviii. of the Transactions of the Novo-Rossisk Society of Naturalists, of Odessa, shows that the labours of a relatively small body have produced very important results. The work opens with an appreciation of the late president, Prof. R. A. Prendel. Botanists will delight in the exhaustive examinations during two summers by $\mathrm{Mr}$. I. Okinshevitch of the forests of northern Bessarabia, which, he says, "in spite of the rich and abundant nature of this country, is very little known from the natural history point of view." The Pliocene and post-Pliocene deposits in south Bessarabia are the subject of a study by Mr. Grigorovitch-Berezovsky. Mr. M. S. Pantchenko describes the hydrological work of the late Admiral S. O Makaroff; it was he who finally settled disputed points with regard to the navigation of the Bosphorus, after careful survey; the cruise of the Vitiaz round the world resulted in the collection of comparative data from different seas; but Makaroff is perhaps best generally known as the designer of the ice-breaker Yermak. His untimely death deprived Russia of one of her greatest practical men of science. Mr. A. Brauner writes extensively on the reptiles and amphibia in several provinces. The volume concludes with the report of the society for I904.

The Tungus race of Siberia has been studied by Mr. S. Patkanoff, who devotes a volume to the Tunguses proper and another to the Manzhurs, Daures, Solones, and other tribes. The Russians first came into contact with the Siberian aborigines early in the seventeenth century, while the Cossacks were extending the conquests initiated by the famous Yermak in the reign of Ivan the Terrible. The Tunguses formerly occupied a large territory, but were driven northwards by the incursions of Buriats, Yakuts, and other Asiatics, as well as of Russians. The Cossacks observed that a certain amount of culture was known to the Tunguses, who wore iron helmets, shields, and chain-mail in battle. The principal occupations of these people are breeding of deer, hunting, and fishing. The pure type is now difficult to trace, owing to admixture with other races for some considerable period. Travellers have paid high tribute to their many excellent qualities in comparison with other Asiatics, especially as regards honesty. Middendorf found strong mountaineering characteristics among the Tunguses, probably survivals of an earlier period. Kastren styled them "the noblemen among Siberian tribes." Various tribes are dealt with as carefully by the same author in the second volume, which also contains notes on the languages and dialects, with specimens, a map of Siberia illustrating the distribution of Tungus tribes, and another showing their position in the Amur region. This work evinces the thoroughness with which the Russians are studying and mastering the varying conditions and populations of the vast territories owning the Tsar as sovereign.

Messrs. B. M. Zhitkov and S. A. Buturlin have compiled an interesting volume of materials for the ornithology of the Simbirsk government, though they do not claim that it is exhaustive, and have not covered all the ground. The groups dealt with comprise Pygopodes, Longipennes, NO. I 940, VOL. 757
Limicolæ, Alectorides, Gallinæ, Columbæ, Lamellirostres, Herodiones, and Rapaces. The area is largely broad, cleared steppe country, with a fauna such as might be expected in a corn-growing region. Oases of forest or grass land, with abundance of water at intervals, intersect the monotonous plains, and shelter corresponding forms of animal life. The authors have spent fifteen years in observation and collection of materials.

In a report on a geological investigation extending from Mukden to Liao-yang, shortly before the Russo-Japanese war, Mr. Y. S. Edelstein, a Russian explorer, writes:"Many people consider Manchuria a country of extraordinary richness in minerals. This fame does not rest on sufficient evidence, as in the first place the question of quantities and qualities of useful minerals in Manchuria is still too little known, and in the next, even in the present condition of our knowledge of Manchuria, it is scarcely possible to doubt that many areas of Siberia, the Urals, and Europe surpass it in this respect." Auriferous sand, thanks to barbarous and primitive methods of working, loses the major part of its value in the eyes of a European contractor, and the extensive employment of modern machinery is the only way to secure advantage from working.

In his account of a botanical expedition in Ossetia and Colchis (Transactions of the Imperial Russian Geographical Society, vol. xxxviii., No. 3), Mr. V. V. Markovitch writes that the beech of the Ossetian forests, considered by botanists as being identical with the species Fagus silvatica, L., of western Europe, was discovered by Lipsky to be a new species, and styled by him Fagus orientalis, Lipsky. Lipsky based his conclusions largely upon differences in fruit. Mr. Markovitch finds that the lignine of the Caucasian beech does not resemble that of Fagus silvatica. The German name Rotbuche is due to the colouring of the lignine after hewing, which does not occur in that of the Caucasian variety, which remains white.

THE BRUSSELS SOCIOLOGICAL SOCIETY.

THERE are at the present day many earnest students of sociology. It is only natural, therefore, that we should find societies for the investigation of sociological questions springing up. The publications of the Instituts Solway for 1906 are already fairly bulky, though as yet we have the output for the first half of the year only. There are seven "fascicules," the largest of which contains three hundred pages. One, possibly two, of the papers contained in them, though not to a great extent original, may be described as distinctly able. The aim of the first paper (by E. Solway) is to prove that sociology must be founded on biology. Of course, if the nature of a society is to be investigated, it is well, as a preliminary, to learn all that is to be known about the individuals of which it is composed. It is well to make this clear at the outset, but it may be doubted whether anything is gained by arguing this out elaborately and mathematically.

The second paper (by E. Waxweiler) sketches the methods of sociology. A young science must, of course, try to be ultra-scientific. It is sure to be decried as an upstart that has no right to claim admission to the pantheon of the sciences. It is bound to insist that there shall be no vagueness of terminology, and that words shall be accurately used. Our author is quite right to emphasise the importance of such matters. When he goes on to deal with evolution, we find much with which we cannot agree. The struggle for existence he seems to count almost as a myth, and he would substitute for it the idea of "an irresistible tendency towards life." Such big, vague assumptions are far more unscientific than the casua methods which our author condemns. So at least it seems to the present writer. A little further on we find living organisms divided into three classes--." vegetables, animals, and men."

The third paper (by R. Petrucci) is, like the second, a long one. It deals with the natural origin of property. The author is no doubt right when he maintains that, independently of legislation, there may be property and 1 "Instituts Solway-Travaux de l'Institut de Sociologie." Parts I-5 and 7. (Bruxelles and Leipsig: Misch and Thron, 1906.) 
ownership. When he goes on to assert that plants have property, that a plant "possesses a definite territory," he seems to be playing with words. In the organ-pipe coral he finds an example of collective ownership, the individual polype also having something in the way of private property. In animals of a higher class, e.g. in ants, the notion of property does undoubtedly show itself. This paper is illustrated, and some of the pictures are excellent, but a picture of the nest of Formica rufa does not help us to understand the subject of property.

The fourth paper (by L. Wodon) is brief, and deals trenchantly with some sociological theories, notably with those of Karl Büchner, who maintains that primitive man was a non-social being. This creature of theory lived in lands where the abundance of natural products made any large output of energy on his part quite unnecessary. Our author satisfactorily disposes of this primitive lotus-eater.

Dr. E. Houzé has contributed a distinctly able paper (fascicule No. 5) on the Aryan and anthroposociology. $\mathrm{He}$ has a thorough grasp of his subject, his style is clear, and he has a fine sense of humour. The wonderful theories of the comparative philologist he sends to the limbo to which such theories must sooner or later find their way. He goes rather too far when he maintains that the Aryans were the creatures of the philologists. It is true, no doubt, as he argues, that no race has ever maintained its purity for any length of time unless it happened to be geographically secluded. The pure-bred Aryan stock that we were taught to picture to ourselves ranging over great part of Asia and all of Europe is a myth. But it is difficult to believe that the people who spoke the Aryan tongue in different parts of the world had not a fairly strong strain of kindred blood in them, though they intermarried freely with the tribes and peoples among whom they found themselves. Still, far too much has been made of the Aryans as a separate type, and Dr. Houzé is right to laugh at what has been called "Anglo-Saxon pandolichocephalism," a term invented to describe " the skull which has the honour of sheltering the brain that has guided the world." M. de Lapouge, the champion of the "dolichocephalic blond Aryan," is very severely dealt with. Dr. Houzé is a strong believer in natural selection. He keeps quite clear of the untenable view that it goes on in the organic world generally, whereas among men it has somehow become a thing of the past. "When the sun has baked the grass," he remarks, "it forces innumerable troops of antelopes to migrate : is not this the same cause that drives the Germans to embark at Hamburg for America? It is a question of food." Archarology, he holds, supplies the firmest foundation for anthropology, and he speaks with great respect of such men as de Morgan, Arthur Evans, and Flinders Petrie. Anthropometry he puts in its proper place. Nothing can be more absurd, as he says, than to make size of skull alone an absolute measure of brain capacity. When he discusses existing populations and their characteristics, Dr. Houzé shows great soundness of judgment. As to the question of town and country life, he holds that the commonly held opinion that towns "devour their inhabitants with rapidity " is at any rate an exaggeration. On the modernism of Teutonic civilisation he makes some very sensible remarks. The Teutons appeared late on the stage of history, and it was only their contact with GalloRoman civilisation that enabled them to reduce their legends to writing.

The last of the papers we are reviewing (by R. Petrucci) takes pains to prove that animal associations were developed independently of one another. They do not form the descent of birds and of men from simpler forms of life, the author shows a thorough understanding of the subject. About animal societies he has much interesting information-about the sociability of reptiles, about the form the family takes among fish, birds, and mammals. Apparently he does not point out (a curious omission) the interesting fact that the pairing instinct is strong only in those species in which the energy of both parents is required for the feeding or protection of the young. We regret that we have not space to deal more fully with this last paper. Those who are interested in animal associations would do well to study it.

NO. I 940, VOL. 75]

\section{IS THERE DETERMINATE VARIATION?}

$\mathrm{IN}$ an article published in Science of November 16, Prof.

Vernon L. Kellogg, of Stanford University, discusses the question as to the existence among organisms of determinate variation, that is to say, variation in the same or a similar direction in a large number of individuals of a single species. If such a factor does exist, one of the objections to the origin of species by natural selectionnamely, that small individual variations would be eliminated in a generation or two-disappears.

Prof. Kellogg's observations refer to variation occurring in the Californian flower-beetle, Diabrotica soror, inhabiting the Stanford University "campus." Large series of this chrysomelid beetle, varying from 500 to 1500 in number, were collected on that area in the years 1895 , I901, 1902, 1904, and 1905. Normally, the beetle shows six dark spots arranged in pairs on each wing-cover. Individuals show, however, a tendency to the transverse coalescence of the two middle or two lower spots on one or both elytra, or a longitudinal fusion of the three spots on each half of the elytron. In 1895 the majority of the beetles had twelve free spots on the two elytra, but among the variations there was a marked tendency to the transverse union of the two middle spots, either on one or both elytra, the percentage being 22.40 . In the years $1901-5$ a much larger percentage of this variation occurred, reaching 53.92 per cent. in one series in 1905 , and 65.40 per cent. in 1904 .

After adducing arguments to show that the variation is neither ontogenetic (that is, determined for each generation during development by external influences) nor the result of natural selection, Prof. Kellogg falls back on determinate variation. "If," however, he writes, "determinate variation is the explanation of this change in Diabrotica soror it is a determinate variation which is occurring only, apparently, in our particular locality. For in series of specimens of this beetle collected in other parts of California no such change seems to be going on, the old twelve-spots-free form being plainly the modal type. . . Why the species should be changing on our university campus and not changing in the regions south and north of us is a mystery whose solution I do not even dare to guess at. This solution must have to do with the cause of the variation of the species on our campus. But if one asks what is this cause, what it is that is producing determinate variation in Diabrotica, or in any other species, it must be mentioned that prior to any attempt to explain how determinate variation might be produced it is advisable to attempt to determine if determinate variation really exists. Is there determinate variation?"

\section{UNIVERSITY AND EDUCATIONAL INTE LLIGENCE.}

Lord Curzon of Kedleston, who was appointed to be the Romanes lecturer at Oxford for 1906, but was prevented from delivering the lecture, has been appointed the Romanes lecturer for this year.

Mr. William Smith, of Geneva, has, says Science, given Ioo, oool. to Hobart College to endow a college for women. It is also announced that Dr. Andrew Carnegie has offered to give 20,0ool. to Queen's University, Ontario, on condition that an additional sum of $80,000 \bar{l}$. be collected.

Mr. J. D. Rockefeller has made a New Year's gift to Chicago University of about $600,000 l$, which brings his total benefactions to the University up to $3,900,000 l$. The private gifts to universities and colleges in the United States, announced in these columns during last year, amounted to nearly $5,000,000 l$.

THE annual meeting of the Public School Science Masters' Association will be held at the University of London on Saturday, January 12. The president, the Rev. the Hon. E. Lyttelton, headmaster of Eton, will take the chair, and will read a paper on the place of science and of literature in a general education. Other subjects of papers upon which it is hoped discussion will take place are :- “The Internal Economy of School Science," by Mr. Thwaites, and "The Best Method of Introducing the Atomic Theory in Science," by Mr. F. R. L. Wilson. 